\title{
Comparative Analysis of Participation of Teachers of STEM and Non-STEM Subjects in Professional Development
}

\author{
Edward T. Chiyaka ${ }^{1}$, Joachim Kibirige ${ }^{2}$, Alec Sithole ${ }^{3}$, Peter McCarthy ${ }^{4}$, Davison M. Mupinga ${ }^{5}$ \\ ${ }^{1}$ Department of Health Policy and Management, College of Public Health, Kent State University, USA \\ ${ }^{2}$ Department of Economics, Political Science and Sociology, Missouri Western State University, 4525 Downs Drive, St. \\ Joseph, MO 64507, USA \\ ${ }^{3}$ Department of Computer Science, Mathematics and Physics, Missouri Western State University, 4525 Downs Drive, St. \\ Joseph, MO 64507, USA \\ ${ }^{4}$ Mathematics Department, Lane College, 545 Lane Ave, Jackson, TN 38301, USA \\ ${ }^{5}$ Teaching, Learning, and Curriculum Studies, Kent State University, 404 White Hall, Kent, OH 44242, USA \\ Correspondence: Edward T. Chiyaka, Department of Health Policy and Management, College of Public Health, Kent \\ State University, USA.
}

Received: July 5, 2017

doi:10.11114/jets.v5i9.2527
Accepted: July 23, $2017 \quad$ Online Published: July 28, 2017

URL: https://doi.org/10.11114/jets.v5i9.2527

\begin{abstract}
School administrators continuously consider teacher professional development (PD) as one of the key strategies to improving teachers' pedagogical skills. Modern proposals for advancing education by improving student learning outcomes are centered on high quality professional development for teachers. However, teachers face a number of barriers when it comes to participation in PD. Also, students in K-12 levels taking Science, Technology, Engineering, and Mathematics (STEM) and non-STEM subjects often report different learning experiences, most of which influence their decisions to enroll in STEM or non-STEM career-related programs in higher education. Understanding factors that influence the differential in teacher participation in PD is a critical step towards addressing student interest in STEM careers. Using the cross-sectional survey data from the Teaching and Learning International Survey of 2013, this study compared the participation of middle school STEM and non-STEM teachers in PD activities in the US. A bivariate analysis was used to compare STEM subject teachers versus non-STEM subject teachers' participation in PD activities, its impact, and challenges. The findings showed that PD participation was higher among teachers of STEM subjects, but not significantly different from those for non-STEM subjects. Out-field teaching (no formal training of subject taught) accounted for $10.3 \%$ of the survey participants. Further, conflict with one's work schedule was one of the major barriers to PD participation for teachers.
\end{abstract}

Keywords: STEM subjects, professional development, teacher participation, barriers

\section{Introduction}

Middle school is a critical stage where students start to make decisions on whether to pursue science, technology, engineering, and mathematics (STEM) or non-STEM programs in college. In order for the US to stay globally competitive in terms of innovation and invention, the teaching of STEM has to become a priority in K-12 education today (Avery \& Reeve, 2013). As the need for students to become stronger in STEM grows, so does the need for well-qualified teachers, who understand what is needed to develop relevant opportunities for those involved in STEM education. Currently, in the US, there is a call to increase students in STEM that places more emphasis on inquiry based learning approaches in STEM education.

The choices that students make on whether to pursue STEM or non-STEM related careers, mostly depend on their learning experiences and comparative view of teaching and assessment methods in STEM and non-STEM classes. Beginning from the middle to high school levels, studies have shown that students' interest in STEM subjects wanes dramatically (Hall, Dickerson, Batts, Kauffmann, \& Bosse, 2011). Professional development (PD) has been one of the methods used to in-service teachers to remain abreast with advances in teaching technology, changing student needs and academic standards, subject content, and new classroom management techniques in the face of changing teaching and 
learning standards. Already, the Next Generation Science Standards (NGSS) have been proposed as a new set of guidelines for K-12 science content standards, and currently 17 states have adopted them (Isabelle, 2017).

About $14 \%$ of US teachers leave the classroom after one year of teaching experience, and $46 \%$ quit the teaching job before their fifth year in the teaching service (Auguste, Kihn, \& Miller, 2010). The question is "what are the reasons for the high teacher turnover?" Many educators explain that pressure to raise students' test scores causes teachers to experience more stress and less job satisfaction (Moore, 2012). Other researchers point to burnout as a very likely explanation (Fisher, 2011; Otero López, Castro Bolaño, Santiago Mariño, \& Villardefrancos Pol, 2010). However, some studies consider meaningful teacher professional development as having a significant influence on teacher retention (Borko, 2004; Özer \& Beycioglu, 2010; Reynolds, Ross, \& Rakow, 2002; Waddell, 2010).

The major differences between STEM and non-STEM courses remain a topic of discussion. Even within the similar disciplines, the differences are widespread for every subject (Su \& Rounds, 2015). Often, STEM subject content is interconnected between the same and different subjects, and such progression of content affects student learning experiences. Due to the differences in the learning expectations in STEM and non-STEM subjects, Laird, Shoup, Kuh, and Schwarz (2008) reported that STEM faculty use significantly different pedagogies than their counterparts teaching non-STEM subjects. The major differences cited in the teaching styles include encouraging integrative and reflective learning. They found lower expectations for integrative and reflective learning among STEM teachers compared to teachers in other fields. These differences in learning styles mean that students taking STEM subjects may not be able to develop the same level of intellectual self-reflection skills like students in non-STEM subjects. In the teaching sector, PD refers to activities that provide opportunities for educators to improve the quality of teaching practices, subject knowledge, or challenging existing beliefs/attitudes for the benefit of students (Timperley, 2011). These activities aim to promote capacity-building of adaptive educators, learning how to teach, transformation of knowledge into practice, and deep pedagogical content and evidence-based assessment knowledge to improve the learning outcomes for students, and to exchange knowledge on professional standards for learning (Broad \& Evans, 2006; Timperley, 2011). According to Fullan (1991), PD is "the sum of all one's formal and informal learning experiences through one's career from pre-service teacher education to retirement" (p. 326). Two classes of PD exist: a) traditional PD, which comprises short workshops, conferences, and seminars; and b) non-traditional PD, which includes mentoring, coaching, and peer observation (Bayar, 2014).

Some of the expected outcomes of PD include sharing expertise on new and existing educational theories and practices; collaboratively developing new curricula; increasing academic knowledge; cultivating positive teaching attitudes; and skill-sharing on effective questioning strategies (Joyce \& Showers, 2002). These outcomes fall into four broad target areas of professional development: classroom-based learning, collaborative learning, peer-mentoring, and coaching (Walter \& Briggs, 2012). The 21st Century Teacher Development Tool-kit includes the importance of coaching (conducting articulations, creating growth plans for the beginner, intermediate and advanced teacher); demonstrating effective push-in support of strategies, and PD models (Klein, Kathleen, \& Lyles, 2008). When effectively implemented, PD is likely to improve the teacher's content knowledge, pedagogical content knowledge, and the student learning process.

Although the teacher's knowledge of the subject area is required, it is not sufficient to improve student satisfaction. According to Singer, Ross, and Jackson-Lee (2016), teachers need to possess pedagogical skills and resources that enforce student learning experience. School administrators consider PD participation as one of the core strategies for providing or improving the needed pedagogical skills and it is an ongoing process during the life of a teacher. It is also considered as a pathway to the teacher's success and professional satisfaction. Forms of PD include participation in courses/workshops, conferences/seminars, in-service training courses, and observation visits to other schools, businesses, or organizations. However, not all teachers get the opportunity to participate in PD activities.

\subsection{Purpose of the Study}

It has long been accepted that teacher PD is a fundamental process that helps teachers develop their critical skills to enhance student success, good classroom management, expansion of knowledge in subject areas, curriculum innovation, professionalism, and passion for teaching (Guskey, 2002). However, participation in professional development activities varies within school districts, subject areas taught, and needs of individual teachers. The purpose of this study was to compare the participation of teachers in PD activities and the effectiveness of PD on teaching between STEM teachers and teachers of non-STEM subjects at the middle school level in the US. Specifically, this study sought to:

a) Describe the demographic characteristics of the STEM and non-STEM teachers who participated in PD activities.

b) Identify the nature of professional development activities for the STEM and non-STEM teachers. 
c) Determine the impact of the professional development activities, as reported by the participating teachers.

d) Identify barriers to participation in professional development activities for STEM and non-STEM teachers.

\subsection{Significance of the Study}

There is need to address the disparities in student learning experiences between STEM and non-STEM subjects. One common practice in achieving this goal is through the use of teacher PD. However, there are concerns that PD is not effectively impacting student learning as desired. Penuel, Harris, and DeBarger (2015), identified three major components required to make PD effective: 1) they should be student oriented; 2) they should be sustained over time to be able to measure their effectiveness; and (3) they must be linked to classroom activities. Therefore, PD can be an essential platform to improve student learning experiences if they meet the teachers' needs (Killion, 2017). Our study examined different modes of PD activities in which teachers of STEM and non-STEM subjects participated in, examined the level of participation, challenges that impede teacher participation, and their level of satisfaction in PD. Understanding levels of participation and challenges faced in PD may help in efforts that seek to find lasting solutions to help STEM teachers develop critical skills in STEM teaching and general professionalism in STEM Education thereby enhancing the students' success.

\subsection{Limitations of the Study}

Data for this study was based on an international survey of lower secondary education teachers and principals in the year 2013 coordinated by the Organization for Economic Cooperation and Development (OECD) (OECD, 2014). Though over thirty countries participated in the survey, this study focuses on teachers in the US only. Since we considered the US data file and also focused only on US teachers, results cannot be generalized to reflect teachers in all countries.

\section{Materials and Methods}

\subsection{Data, Inclusion, and Exclusion Criteria}

Data used were from the Teaching and Learning International Survey (TALIS), an international survey of lower secondary education teachers and principals coordinated by the Organization for Economic Cooperation and Development (OECD) (OECD, 2014). The US, along with more than 30 other countries participate in the survey where school principals and teachers provide information about issues such as the professional development they have received; their teaching beliefs and practices; review of teachers' work; the feedback and recognition they receive about their work; and various other school leadership, management and workplace issues. Our study utilized the US national public-use data files, which include all variables in the US international data files but also the US specific variables that are not part of the US international data files. The study excluded participants who had missing data on the outcome of interest, professional development participation, and other key characteristics including age, employment status, and teacher training. This resulted in a final sample of 1,856 included in the analysis.

\subsection{Measurement of Key Variables}

Professional Development (PD): In the questionnaire, teachers were asked to indicate if they had participated in any of the following activities: courses and workshops; education conferences and seminars; observation visits to other schools, businesses or organizations; and participation in in-service training courses in business organizations. Any participation in any of these activities was considered as a form of professional development.

STEM Teachers: Teachers were categorized as teaching either STEM subjects or non-STEM subjects. Subjects classified as STEM subjects included mathematics, science, and technology courses, while non-STEM subjects included social studies, language subjects, arts, religious studies, education and reading, writing and literature. Other data, such as practical and vocational skills, which were neither purely STEM nor non-STEM, were excluded.

\subsection{Teacher Characteristics}

We used measures of teacher demographics including gender; age; employment status (full or part time); highest level of education (tertiary education vs less than tertiary education); teacher education training; years of teaching experience; and components included in the formal education or training (content of subjects, pedagogy of subjects, and classroom practice).

\subsection{Statistical Analysis}

Bivariate analysis was used to compare STEM teachers versus non-STEM teachers with regard to describing 1) professional development participation, 2) its impact, and 3) the barriers encountered. Analyses were performed using SAS version 9.3 (SAS Institute Inc.,) statistical software. Since the TALIS study utilizes a complex survey data system, sampling weights with a complex multi-stage cluster sample were applied. 


\section{Results}

The average age of the teachers was 42.2 (SD 11.3) years and most of them had spent more than 15 years as teachers. The majority of the participants were females, employed full time, had some teacher education training and had some tertiary education as their highest level of formal education completed. When classified according to teaching either STEM subjects or not, there was no significant difference in age, years of teaching, gender, employment status and highest level of education. On teacher education training, non-STEM teachers were more likely not to be teacher trained when compared to those teaching STEM subjects. Also, between $6 \%$ and $11 \%$ of the participants indicated that content, pedagogy, and classroom practice of subject taught were not included in their teacher training program. Table 1, shows the summary of socio-demographics and other characteristics of the participants.

Table 1. Socio-demographics and other characteristics of teachers $(n=1856)$

\begin{tabular}{|c|c|c|c|}
\hline Characteristics & $\begin{array}{l}\text { Overall frequency } \\
\text { Unweighted n (\%) }\end{array}$ & $\begin{array}{l}\text { STEM Teachers } \\
(\%)\end{array}$ & $\begin{array}{l}\text { Non-STEM Teachers } \\
(\%)\end{array}$ \\
\hline \multicolumn{4}{|l|}{ Gender } \\
\hline Male & $621(35.0)$ & 36.7 & 33.4 \\
\hline Female & $1235(65.0)$ & 63.3 & 66.6 \\
\hline \multicolumn{4}{|l|}{ Age (years) } \\
\hline Less than 30 & $345(18.6)$ & 18.4 & 18.9 \\
\hline $30-40$ & $530(28.6)$ & 25.9 & 30.3 \\
\hline $41-50$ & $485(26.1)$ & 26.6 & 25.0 \\
\hline $51-60$ & $385(20.7)$ & 23.4 & 19.5 \\
\hline More than 60 & $111(6.0)$ & 5.8 & 6.4 \\
\hline \multicolumn{4}{|l|}{ Employment Status } \\
\hline Full-time & $1799(96.2)$ & 96.5 & 95.9 \\
\hline Part-time & $57(3.8)$ & 3.5 & 4.1 \\
\hline \multicolumn{4}{|l|}{ Teaching experience (years) } \\
\hline Less than 5 & $397(21.4)$ & 22.4 & 21.0 \\
\hline $5-10$ & $427(23.0)$ & 23.1 & 25.5 \\
\hline $11-15$ & $364(19.6)$ & 18.2 & 18.5 \\
\hline More than 15 & $668(36.0)$ & 36.3 & 35.1 \\
\hline \multicolumn{4}{|l|}{ Highest level of education } \\
\hline Less than tertiary education ${ }^{\mathrm{a}}$ & $26(1.5)$ & 1.3 & 1.7 \\
\hline Some tertiary education ${ }^{\mathrm{b}}$ & $1828(98.5)$ & 98.7 & 98.3 \\
\hline \multicolumn{4}{|l|}{ Teacher Education Training } \\
\hline Yes & $1783(94.7)$ & 96.4 & 93.0 \\
\hline No & $73(5.3)$ & 3.6 & 7.0 \\
\hline \multicolumn{4}{|l|}{ Content of subject taught } \\
\hline Yes & $1739(93.9)$ & 92.9 & 95.1 \\
\hline No & $116(6.1)$ & 7.1 & 4.9 \\
\hline \multicolumn{4}{|l|}{ Pedagogy of subject taught } \\
\hline Yes & $1718(91.8)$ & 93.2 & 90.3 \\
\hline No & $137(8.2)$ & 6.8 & 9.7 \\
\hline \multicolumn{4}{|l|}{ Classroom practice of subject taught } \\
\hline Yes & $1691(89.7)$ & 90.1 & 89.4 \\
\hline No & $164(10.3)$ & 9.9 & 10.6 \\
\hline
\end{tabular}

${ }^{\mathrm{a}}$ Individuals with pre-primary education, primary education, lower secondary education, upper secondary education, and post-secondary non-tertiary education. UIC, 2009, Global Education Digest, Annex C.

${ }^{\mathrm{b}}$ Individuals who have some tertiary education qualification. Source: UIC, 2009, Global Education Digest, Annex C.

\subsection{Professional Development Participation}

As outlined earlier, teachers are exposed to different professional development activities during their tenure and there are variations in the nature and level of participation. Overall, about $91 \%$ of the teachers had participated in at least one form of professional development activity. Our findings indicate that STEM teachers are more likely to participate in courses and workshops; education conference and seminars; observation visits to other schools; businesses or organizations; and in-service training courses when compared to non-STEM teachers. The mean duration of participation varied across different activities and depended on whether the teacher is a STEM teacher or not. Participation in courses and workshops had the highest mean duration ( 8.8 days) when compared to other professional development activities for both STEM teachers and non-STEM teachers as shown in Table 2. When the mean duration of professional development activities was compared between STEM teachers versus non-STEM teachers, the results 
show that STEM teachers were more likely to spend more time in professional development activities than non-STEM teachers, except for participation in observation visits to other schools, which favored the non-STEM teachers. There were no significant differences in median duration for participation for most PD activities except for participation in observation visits to business or organizations which was statistically significantly different between STEM and non-STEM teachers $(\mathrm{P}<.0 .05)$.

Table 2. Participation in professional development activities for STEM and non-STEM teachers

\begin{tabular}{|c|c|c|c|c|c|}
\hline \multirow[t]{2}{*}{ Professional Development Activity } & \multicolumn{2}{|c|}{$\begin{array}{l}\text { Participation } \\
(\%)\end{array}$} & \multicolumn{3}{|c|}{$\begin{array}{l}\text { Mean duration of participation } \\
\text { in days (SD) }\end{array}$} \\
\hline & STEM & Non-STEM & STEM & Non-STEM & p-value ${ }^{a}$ \\
\hline Participation in courses and workshops & 82.9 & 85.8 & $8.8(21.6)$ & $8.1(19.3)$ & .47 \\
\hline $\begin{array}{l}\text { Participation in education conferences and } \\
\text { seminars }\end{array}$ & 49.7 & 48.1 & $4.0(6.1)$ & $3.4(4.5)$ & .12 \\
\hline Participation in observation visits to other schools & 14.2 & 12.1 & $3.0(6.0)$ & $3.3(11.9)$ & .76 \\
\hline $\begin{array}{l}\text { Participation in observation visits to business or } \\
\text { organizations }\end{array}$ & 8.8 & 4.6 & $4.0(7.5)$ & $2.0(1.5)$ & $.01 *$ \\
\hline $\begin{array}{l}\text { Participation in in-service training courses in } \\
\text { business premises }\end{array}$ & 15.6 & 14.5 & $4.5(5.8)$ & $3.6(4.6)$ & .19 \\
\hline
\end{tabular}

${ }^{\mathrm{a}} P$ values from the $t$ test of mean duration of participation.

*Indicates a significant difference in median duration times.

\subsection{Impact of Professional Development on Teaching}

Most teachers indicated that PD has had a positive impact on their teaching. Those teaching non-STEM subjects were more likely to report positive impact on teaching in a multicultural and multilingual setting when compared to their counterparts teaching STEM subjects. On knowledge and understanding of subject field, both STEM and non-STEM teachers indicated a very high positive impact (more than 99\%). Overall, the highest reported impact due to participation in PD as reported by teachers was knowledge and understanding of subject field while teaching in multicultural and multilingual settings had been impacted the little. Only school management and administration showed a significant difference $(\mathrm{P}<.05)$ in positive impact between STEM and non-STEM teachers. Table 3 summarizes the impact of professional development on teachers teaching STEM and non-STEM subjects.

Table 3. Impact of professional development on teaching

\begin{tabular}{|c|c|c|c|}
\hline \multirow[t]{2}{*}{ Item } & \multicolumn{2}{|c|}{ Positive Impact } & \multirow[b]{2}{*}{ p-value ${ }^{a}$} \\
\hline & STEM $(\%)$ & Non-STEM $(\%)$ & \\
\hline Knowledge and understanding of my subject field & 99.1 & 99.2 & .83 \\
\hline Pedagogical competencies in teaching my subject field & 99.0 & 99.0 & .94 \\
\hline Knowledge of the curriculum & 98.7 & 99.1 & .55 \\
\hline Student evaluation and assessment practices & 97.6 & 98.9 & .10 \\
\hline Information and communication technology skills for teaching & 99.2 & 98.6 & .41 \\
\hline Student behavior and classroom management & 97.1 & 95.4 & .25 \\
\hline School management and administration & 99.7 & 92.8 & $.002 *$ \\
\hline Approaches to individualized learning & 98.1 & 98.1 & .95 \\
\hline Teaching students with special needs & 96.6 & 98.3 & .14 \\
\hline Teaching in a multicultural and multilingual setting & 93.7 & 96.6 & .15 \\
\hline Teaching cross-curricular skills & 97.5 & 97.8 & .77 \\
\hline $\begin{array}{l}\text { Developing cross-occupational competencies for future work or future } \\
\text { studies }\end{array}$ & 98.4 & 96.6 & .31 \\
\hline New technologies in the work place & 98.7 & 98.2 & .54 \\
\hline Student career guidance and counselling & 98.3 & 95.5 & .24 \\
\hline
\end{tabular}

*Indicates a significant difference in median duration times.

${ }^{\text {a }} P$ values from the $t$ test of mean duration of participation.

\subsection{Barriers to Professional Development}

Teachers face many challenges that hinder them from participating in various professional development activities. Overall, not having the pre-requisites to participate in specific professional development activities and lack of employer support were cited as the major barriers to PD. Teachers in non-STEM subjects alluded to not having the pre-requisites; prohibitive costs of participation; lack of employer support; and lack of relevant professional development opportunities as barriers to professional development. On the other hand, teachers in STEM subjects were more likely to indicate 
conflicts with work schedule; family responsibilities; and lack of incentives to participation as barriers to PD when compared to teachers in non-STEM subjects. Table 4 summarizes some of the challenges that teachers face.

Table 4. Barriers to professional development

\begin{tabular}{|c|c|c|c|}
\hline Characteristics & $\begin{array}{l}\text { Overall } \\
\text { Unweighted n (\%) }\end{array}$ & $\begin{array}{l}\text { STEM Teachers } \\
(\%)\end{array}$ & $\begin{array}{l}\text { Non-STEM Teachers } \\
(\%)\end{array}$ \\
\hline I do not have the pre-requisites & $96(5.2)$ & 4.4 & 6.0 \\
\hline Is too expensive/unaffordable & $549(30.4)$ & 29.4 & 31.4 \\
\hline There is a lack of employer support & $398(20.6)$ & 20.5 & 20.6 \\
\hline Professional development conflicts with my work schedule & $827(45.7)$ & 46.6 & 44.7 \\
\hline I do not have time because of family responsibilities & $718(38.6)$ & 40.4 & 36.9 \\
\hline There is no relevant professional development offered & $508(27.4)$ & 27.2 & 27.5 \\
\hline There are no incentives for participation & $845(43.9)$ & 45.5 & 42.2 \\
\hline
\end{tabular}

\section{Discussion}

Using a population based data set, we demonstrated that there are no significant differences in levels of participation in most PD activities between STEM teachers and non-STEM teachers. Only participation in observation visits to business or organizations showed a significant difference and STEM teachers were shown to spend an average of 2 days more on this activity when compared to non-STEM teachers participating on the same. The lack of difference in participation across the two groups demonstrates that PD is not being focused on developing specific teacher skills. This is in sharp contrast to studies that have shown that PD is more effective when it is focused on the content of the subject taught (Rotermund, DeRoche, \& Ottem, 2017). Furthermore, instructional improvement has been linked with sustained and regular activities for teachers grounded in their everyday teaching practice, opportunities to learn from colleagues through collaboration, coaching and wise use of technology (DeMonte, 2013). While our study findings show that teachers have been exposed to some of these practices, there is clear evidence of lack of sustained and regular activities. It is critical that professional development be aligned with the curriculum and subject matter in order to improve the teacher's knowledge of the subject matter. Resources permitting, participation in PD should be ongoing to allow for changing environment especially among Science, Technology, Engineering, and Mathematics teachers. Also, the specific content of the PD is very crucial. According to Welch-Ross, Wolf, Moorehouse, and Rathgeb (2006), the development of PD activities must address the following questions: what works for whom, within which contexts, and at what cost? It is not just in terms of what subjects they teach but also in terms of generation. Sheridan, Edwards, Marvin, and Knoche (2009), identified three major stages to improve PD effectiveness: (a) increasing awareness of new pedagogical approaches needed to achieve desired teaching outcomes; (b) applying the new strategies; and (c) implementation and masterly practice. Therefore, until the issue of content is clarified, PD remains an abstract concept that assumes one shoe "fits all".

The study did not find any major differences between STEM and non-STEM teacher participation in PD. This observation could be accounted for by the fact that there is, after all, not that much difference in knowledge content between STEM and non-STEM teachers at this level. In the overall sense, each teacher really has one specialty, the specialty that was their major at college (if they went to college). Yet, most of the teachers teach a cluster of classes. A Biology major qualifies to teach "Science" just as a Chemistry or Physics major does (Parker, 2017). Yet, "Science" incorporates specific subjects like Physics, Chemistry, Biology, Mathematics, etc. Likewise, a History teacher teaches "Social Studies" which includes History, Political Science, Sociology, Economics, Geography, etc. Intriguingly, in many cases, some teachers may not even have taken a single class in the subject they teach, such as Sociology or Political Science. This generalized nature of the teachers' knowledge base makes the job description of the teacher rather vague in terms of specific content and this affects the nature of the PD required. At the Higher Education level, professional development clearly means advancing oneself in one's area of expertise and the content and goals are clear-cut. PD at the middle school level is more likely to focus on teaching "methods" which are likely to vary little between the different subjects. For the most part, it is mostly grasping classroom-based presentation. While content is covered, it is just one item out of the very many, as is indicated in the list of contents of the conferences (K-12 Teachers' Alliance, 2010). It is also important to factor in the fact that the job of a school teacher, like the content itself, is a "dead-end" one. The knowledge itself is very "standard" and basic that it becomes even difficult to justify professional development. Being static as it is, therefore, it makes the job repetitive, year after year and, therefore, unexciting. This may also account for the fact that the job has no advancement system. The best reward a great teacher is likely to get is a "Teacher of the Month", Teacher of the Year" Award!

Regarding the (slight) difference in STEM versus non-STEM participation in PD, it is also not very surprising, and might even be expected. STEM subjects are more likely to have new information and developments in the field than non-STEM subjects. The Periodic Table in Chemistry is constantly changing; new discoveries are being made in Biology and Physics, etc. On the other hand, the History of Europe and the American Civil war all remain the same. While changes take place in 
all fields, those in other fields, especially non-STEM, are common to all and may not require professional development.

Related to all this is the fact that in many schools, the environment has not changed in decades. Translating this into PD terms, it means that the teachers may be lagging behind their students in areas like technology use especially with the growing online learning and sharing of material. Unlike higher education where there is constant renewal through regular scholarship activities such as attending conferences and conducting research, there is no equivalent opportunity for middle school teachers. Thus, some teachers at schools with limited resources may not evolve in knowledge with the changing learning environment. In addition to the generational differential, another factor is gender. As noted, women are over-represented in the school teacher population. This gender difference can be explained in terms of gender occupational stratification within the overall society. Being a school teacher is regarded as a "female" job and, as such, the majority of school teachers are female. According to the US Department of Education, in 2011/2012, 76\% of all public-school teachers were female (Snyder, de Brey, \& Dillow, 2016). Since the children in middle school are still very young, the job inevitably includes a lot of nurturing and literally "baby-sitting". These "caring" roles are associated with women (mothering). As evidence of this, the gender differences tend to close as we move into high school, and by post-secondary level, the pattern is reversed, whereby the number of male college professors is in preponderance.

Our findings also show that perceptions of barriers to PD participation were almost uniform across the two groups of teachers. These barriers were high cost of PD attendance; lack of employer support; conflicts with work schedule and family demands; poor planning and lack of relevance in PD activities offered; and lack of incentives for participation. The challenge to balance work and family responsibilities with PD activities was also reported and discussed in detail elsewhere (Hayden, Ouyang, Scinski, Olszewski, \& Bielefeldt, 2011). Consistently, high expectations for teachers, but limited resources for professional support were reported by Sheridan et al. (2009). Thus, while professional development is the vehicle for introducing curriculum and pedagogical reforms in education (Carr et al., 2005), the planning phase remains an area of further investigation. According to Petrie and McGee (2012), planners tend to assume teachers that would learn from PD activities and simply apply knowledge in their classroom settings. This according to these authors, overshadows the considerable differences in needs, content knowledge and preparation that exist among teachers. These views corroborate the findings in our study in which teachers in both groups expressed concerns about the lack of relevance and poor planning of most PD activities.

\section{Conclusion}

Our findings have shown that, overall, there are insignificant demographic between subject STEM vs. non-STEM disciplines except for gender which is skewed more to female teachers. While more teachers of non-STEM subjects were not likely to be teacher-trained than those teaching STEM subjects, we found that the same teachers were likely not to participate in PD activities. This observation seems to defy logic, as one would expect that those teachers with deficiencies in training would be more inclined to pursue training than those already trained. It is quite possible that the ill-prepared teachers are also more likely to be found in ill-equipped schools which cannot afford professional development opportunities. Nevertheless, more teachers of STEM subjects reported positive impacts of PD involving administrative issues such as recording attendance, handing out school information, and other clerical duties, while those who teach non-STEM subjects found PD to be effective on multicultural and multilingual development. In addition, both teachers of STEM and non-STEM ( 99\%) professed the positive impact of Professional Development on their subject knowledge advancement. At the top of the list of the teachers' grievances were, inability to participate in specific PD activities, lack of employer support, and conflicts with work schedule.

\section{References}

Auguste, B. G., Kihn, P., \& Miller, M. (2010). Closing the talent gap: Attracting and retaining top-third graduates to careers in teaching: An international and market research-based perspective: McKinsey.

Avery, Z. K., \& Reeve, E. M. (2013). Developing effective STEM professional development programs.

Bayar, A. (2014). The Components of Effective Professional Development Activities in Terms of Teachers' Perspective. Online Submission, 6(2), 319-327.

Borko, H. (2004). Professional development and teacher learning: Mapping the terrain. Educational researcher, 33(8), 3-15. https://doi.org/10.3102/0013189X033008003

Broad, K., \& Evans, M. (2006). A review of literature on professional development content and delivery modes for experienced teachers: University of Toronto, Ontario Institute for Studies in Education.

Carr, M., McGee, C., Jones, A., McKinley, E., Bell, B., Barr, H., \& Simpson, T. (2005). The effects of curricula and assessment on pedagogical approaches and on educational outcomes. 
DeMonte, J. (2013). High-Quality Professional Development for Teachers: Supporting Teacher Training to Improve Student Learning. Center for American Progress.

Fisher, M. H. (2011). Factors influencing stress, burnout, and retention of secondary teachers. Current issues in education, 14(1).

Fullan, M. (1991). with Stiegelbauer, S.(1991). The new meaning of educational change, 2.

Guskey, T. R. (2002). Does it make a difference? Evaluating professional development. Educational leadership, 59(6), 45.

Hall, C., Dickerson, J., Batts, D., Kauffmann, P., \& Bosse, M. (2011). Are we missing opportunities to encourage interest in STEM fields?

Hayden, K., Ouyang, Y., Scinski, L., Olszewski, B., \& Bielefeldt, T. (2011). Increasing student interest and attitudes in STEM: Professional development and activities to engage and inspire learners. Contemporary Issues in Technology and Teacher Education, 11(1), 47-69.

Isabelle, A. D. (2017). STEM Is Elementary: Challenges Faced by Elementary Teachers in the Era of the Next Generation Science Standards. Paper presented at the The Educational Forum. https://doi.org/10.1080/00131725.2016.1242678

Joyce, B. R., \& Showers, B. (2002). Student achievement through staff development.

K-12 Teachers Alliance. (n.d.). Professional Development for Teachers | K-12 Teachers Alliance. Retrieved July 10, 2017, from http://www.k12teachertraining.com/topics-ddi.html

Killion, J. (2017). Meta-Analysis Reveals Coaching's Positive Impact on Instruction and Achievement. Learning Professional, 38(2), 20-23.

Klein, J. I., Kathleen, G., \& Lyles, M. V. (2008). Professional development opportunities provided by the division of Teaching and Learning. Retrieved from New York City Department of Education Website: http://schools.nyc.gov/NR/rdonlyres/38E1F394-C342-4446-8100-62512C911DE6/0/TLFINAL.pdf

Laird, T. F. N., Shoup, R., Kuh, G. D., \& Schwarz, M. J. (2008). The effects of discipline on deep approaches to student learning and college outcomes. Research in Higher Education, 49(6), 469-494. https://doi.org/10.1007/s11162-008-9088-5

Moore, C. M. (2012). The role of school environment in teacher dissatisfaction among US public school teachers. Sage Open, 2(1). https://doi.org/10.1177/2158244012438888

OECD. (2014). TALIS 2013 Results: An International Perspective on Teaching and Learning: OECD.

Otero López, J. M., Castro Bolaño, C., Santiago Mariño, M. J., \& Villardefrancos Pol, E. (2010). Exploring stress, burnout, and job dissatisfaction in secondary school teachers. International Journal of Psychology and Psychological Therapy, 10(1).

Özer, N., \& Beycioglu, K. (2010). The relationship between teacher professional development and burnout. Procedia-Social and Behavioral Sciences, 2(2), 4928-4932. https://doi.org/10.1016/j.sbspro.2010.03.797

Parker, M. (n.d.). Majors to Become a High School Math or Science Teacher | Chron.com. Retrieved July 8, 2017, from http://work.chron.com/majors-become-high-school-math-science-teacher-3284.html

Penuel, W. R., Harris, C. J., \& DeBarger, A. H. (2015). Implementing the next generation science standards. Phi Delta Kappan, 96(6), 45-49. https://doi.org/10.1177/0031721715575299

Petrie, K. C., \& McGee, C. (2012). Teacher Professional Development: Who is the learner?

Reynolds, A., Ross, S. M., \& Rakow, J. H. (2002). Teacher retention, teaching effectiveness, and professional preparation: A comparison of professional development school and non-professional development school graduates. Teaching and Teacher Education, 18(3), 289-303. https://doi.org/10.1016/S0742-051X(01)00070-1

Rotermund, S., DeRoche, J., \& Ottem, R. (2017). Teacher Professional Development by Selected Teacher and School Characteristics: 2011-12. Stats in Brief. NCES 2017-200. National Center for Education Statistics.

Sheridan, S. M., Edwards, C. P., Marvin, C. A., \& Knoche, L. L. (2009). Professional development in early childhood programs: Process issues and research needs. Early education and development, 20(3), 377-401. https://doi.org/10.1080/10409280802582795 
Singer, J. E., Ross, J. M., \& Jackson-Lee, Y. (2016). Professional Development for the Integration of Engineering in High School STEM Classrooms. Journal of Pre-College Engineering Education Research (J-PEER), $6(1), 3$. https://doi.org/10.7771/2157-9288.1130

Snyder, T. D., de Brey, C., \& Dillow, S. A. (2016). Digest of Education Statistics 2014, NCES 2016-006. National Center for Education Statistics.

Su, R., \& Rounds, J. (2015). All STEM fields are not created equal: People and things interests explain gender disparities across STEM fields. Frontiers in psychology, 6. https://doi.org/10.3389/fpsyg.2015.00189

Timperley, H. (2011). A background paper to inform the development of a national professional development framework for teachers and school leaders. Australian Institute for Teaching and School Leadership (AITSL), 1-26.

Waddell, J. H. (2010). Fostering relationships to increase teacher retention in urban schools. Journal of Curriculum and Instruction, 4(1), 70-85. https://doi.org/10.3776/joci.2010.v4n1p70-85

Walter, C., \& Briggs, J. (2012). What professional development makes the most difference to teachers. A report sponsored by Oxford University Press. Retrieved on July, 20, 2015.

Welch-Ross, M., Wolf, A., Moorehouse, M., \& Rathgeb, C. (2006). Improving connections between professional development research and early childhood policies. Critical issues in early childhood professional development, 369-394.

\section{Copyrights}

Copyright for this article is retained by the author(s), with first publication rights granted to the journal.

This is an open-access article distributed under the terms and conditions of the Creative Commons Attribution license which permits unrestricted use, distribution, and reproduction in any medium, provided the original work is properly cited. 